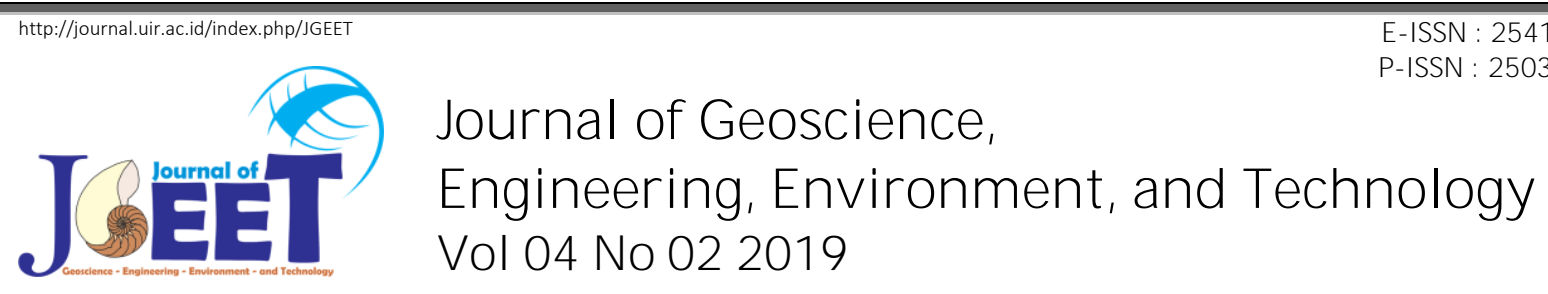

RESEARCH ARTICLE

\title{
Petrogenesis of Volcanic Arc Granites from Bayah Complex, Banten, Indonesia
}

\author{
Jemi Saputra Ahnaf ${ }^{1, *}$, Aton Patonah ${ }^{1}$, Haryadi Permana ${ }^{2}$ \\ 1. Padjadjaran University, Geological Engineering Faculty, Jl. Raya Bandung - Sumedang km 21, Jatinangor, Indonesia \\ ${ }^{2}$ Indonesian Institute of Sciences, Geotechnology Center, JI. Sangkuriang, Bandung, Indonesia
}

* Corresponding author : Jemi14001@mail.unpad.ac.id

Tel.: +62-877-8727-6099

Received: Mei 20, 2019; Accepted: Jun 19, 2019

DOI: $10.25299 /$ jgeet.2019.4.2.3171

\begin{abstract}
This research aimed to reveal the petrogenesis of granitic rocks of Bayah Complex starting from magma differentiation to exposing event, this research also intended to determine the tectonic environment. The methods carried out in this research include field observation, petrographic analysis using polarized light microscopy, and geochemical analysis using X-Ray Fluorescence (XRF) and Inductively Coupled Mass Spectrometry (ICP-MS).

Petrographic analysis shows that Bayah granitic rocks are composed of quartz, plagioclase, and K-feldspar while the rest are amphibole, biotite, sericite, chlorite, epidote, and opaque. Based on its major oxide concentrations, Bayah granitic rocks classified as granite and diorite-quartz which have high- $\mathrm{K}$ calc-alkaline magma. 4 samples of granitic rocks showed the $\mathrm{A} / \mathrm{N}+\mathrm{K}+\mathrm{C}>1 \mathrm{molar}$ ratios belonging to the peraluminous $\mathrm{S}$-type granite index while the remaining 1 sample showed a molar ratio of $\mathrm{A} / \mathrm{N}+\mathrm{K}+\mathrm{C}<1$ and $\mathrm{A} / \mathrm{N}+\mathrm{K}>1$ which classified as metaluminous I-type granite. Accordingly, Bayah granitic rocks are S-type granite which crystallized from sediment-derived magma, the sediments itself estimated sourced from continental especially Malay Peninsula, Indonesian Tin Island, and Schwaner Mountains. During differentiation, the magma undergone crustal contamination reflected by the increase in both $\mathrm{SiO} 20.51$ wt\%and $\mathrm{Al} 2 \mathrm{O} 31.95$ wt\% and decrease in $\mathrm{Fe} 2 \mathrm{O} 3+\mathrm{MgO} 0.61$ wt\%from the pure composition of sediment-derived magma. Furthermore, the occurrence of crustal contamination al so recognized from high concentrations of $\mathrm{Rb}$ and Ba which indicate the interaction of magma with the materials of continental crust.

Regard to the exposing event, Bayah granitic rocks approximated to be exposed due to regional tectonic activity which caused Orogenesa I in the Early Oligocene to the Late Oligocene. Moreover, based on the plot of trace elements especially $\mathrm{Rb}, \mathrm{Y}, \mathrm{Nb}, \mathrm{Ta}$, and $\mathrm{Yb}$ on Harker and tectonic discriminant diagrams, Bayah granitic rocks are formed on volcanic-arc active continental margins in accordance with regional tectonic setting.
\end{abstract}

Keywords: Volcanic-arc, petrogenesis, S-type granite, magma differentiation, Bayah Complex.

\section{Introduction}

The presence of granitic rocks such as granite, monzonite, granodioriteand tonalite are closely related to magmatism. One of the most recognized magmatism activity in western Java Island is Bayah magmatism which formed the Bayah Dome in the Oligocene.

The discovery of granitic rocks in Bayah itself was first reported by Koolhoven (1933) which later discussed also by van Bemmelen (1949); Sujatmiko \& Santosa (1992), Sukarna et al. (1993), and Hartono et al. (2008) known as Granodiorite Cihara. However, only Sukarna et al. (1993) and Hartono et al. (2008) discussed the geochemical signature of these granitic rocks. This research aimed to reveal the petrogenesis and environment of Bayah granitic rock based on field observation, petrography, and geochemistry analyses. Field data was taken from the Cigaber and Cisanun Stream, Lebakpeundeuy Village, Cihara District, Lebak Regency, Banten.

The location of the study itself is known as Bayah Complex due to the discovery of various type of rocks in the same area (Patonah \& Haryadi, 2018; Ahnaf et al., 2018). In addition, the research area also has a complex structural pattern affected by the collision of the IndoAustralian Plate with Eurasia which at least occurred in the Late Cretaceous (Sukarna et al., 1993; Ahnaf et al., 2018). Regional tectonic activity also triggers orogenesis which also contribute to complexity Bayah geological setting. 


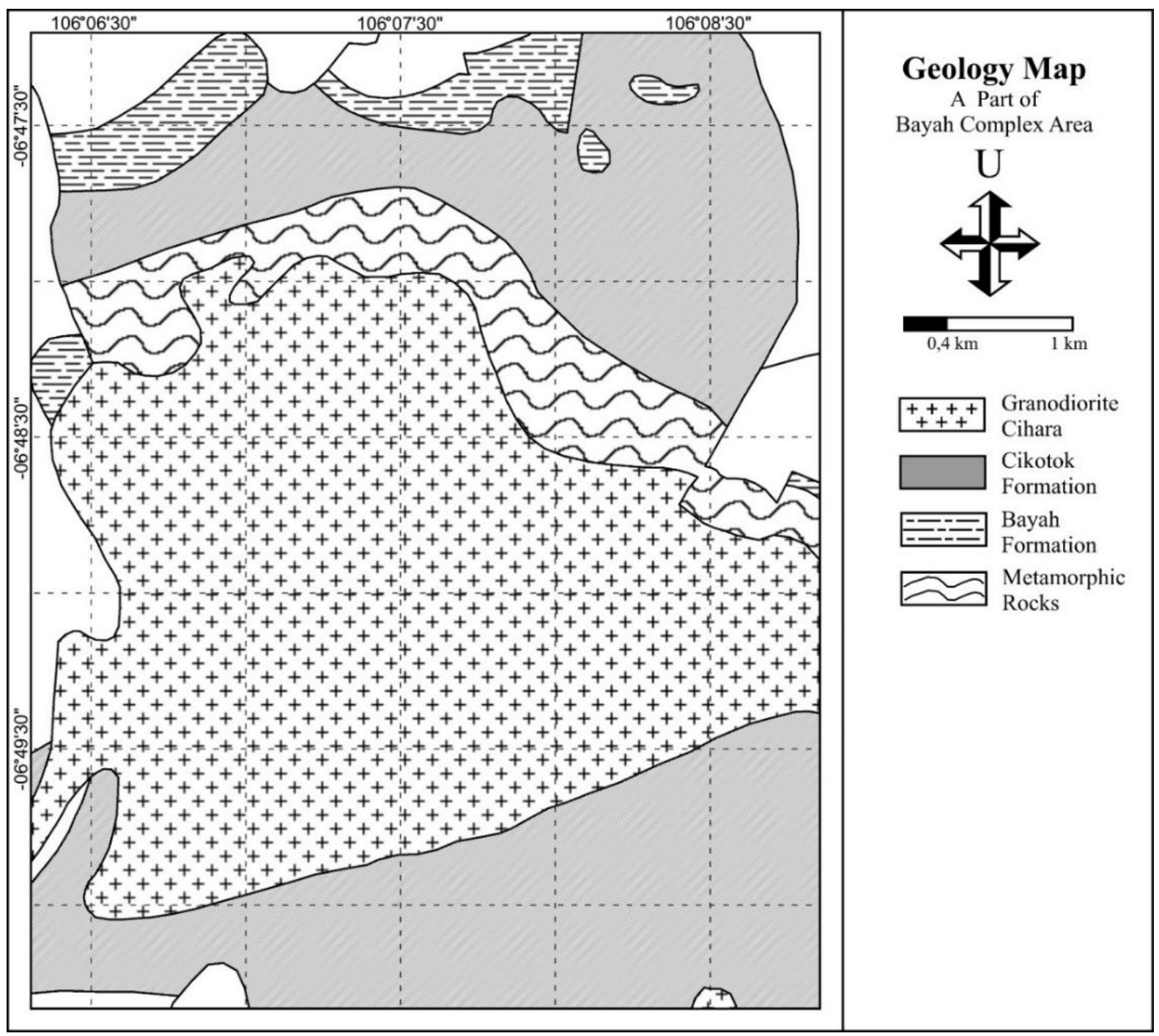

Fig. 1. Modified geological map of the research area after Sujatmiko \& Santosa (1992).

\subsection{Geology Setting}

The regional geology of the research area has been reported in detail by Sujatmiko \& Santosa (1992) in the Leuwidamar Regional Geological Map and the explanatory notes. Some of the rock formations located at the research area i.e. Metamorphic Rock, Bayah Formation, Cikotok Formation, and Cihara Granodiorite, whose distribution shown in Fig. 1. Compilation of several sources regarding the regional geology of the study area is presented as follows:

Metamorphic Rocks: This rock group consisted of schist, quartzite, and amphibolite which can be found in the Cisanun and Cigaber Stream. Sujatmiko \& Santosa (1992) consider these rocks to have the age of the Early Oligocene to the Late Oligocene which in its formation related to contact metamorphism due to granodiorite intrusion which also occurs at the same age. However, the latest research e.g. Patonah et al. (2014); Widiaputra et al. (2016); Patonah \& Haryadi (2018); Ahnaf et al. (2018) stated that metamorphic rocks estimated to be the oldest rocks in Bayah Complex aged as Pre-Tertiary to the Early Eocene. Furthermore, Patonah \& Haryadi (2018) explained that metamorphic rocks found at this location reached epidote-amphibolite to amphibolite facies from the discovery of garnet and hornblende minerals which indirectly stated that these rocks formed in

the regional metamorphism rather than local metamorphism due to intrusion. These metamorphic rocks come from protolith pelitic to psammite sediments and mafic igneous rocks.

Bayah Formation: This formation divided into Limestone Members (Tebl), Claystone Members (Tebm), and Conglomerate Members (Teb) (Sujatmiko \& Santosa, 1992). Around the research area, the Bayah Formation found to be Claystone Member (Tebm) which consists of calcareous claystone, black claystone, shale, and sandstone. The Bayah Formation clearly exposed in south Bayah, Cimandiri, and Banten beach (Sukarna et al., 1993), while around the research area these rocks easily found on the Cipager, Cisanun, and Cimuncang Stream. Based on the radiometric determination of $\mathrm{U}-\mathrm{Pb}$, these rocks estimated to be of the Middle Eocene whose materials sourced from Malay Peninsula, Indonesia Tin Island, and Schwaner Mountains (Clements \& Hall, 2008). Furthermore, Bayah formation estimated that this formation 
deposited in the neritic-paralic environment and influenced several times by tectonic activity which is represented by the presence of reverse faults (Sujatmiko \& Santosa, 1992; Kool hoven, 1933; Sukarna et al., 1993).

Cikotok Formation: This formation also known as Old Andesite Formation (OAF) (e.g. Koolhoven, 1933; Sukarna et al., 1993). This formation consists of volcanic breccia, andesite, basalt, and tuff. Rocks from this formation exposed on the Ciguling, Cihara, and Cimuncang Stream. This formation is the oldest volcanic product that occurred in the research area (Ahnaf et al., 2018) which has the age of the Late Eocene to the Late Oligocene (Sujatmiko \& Santosa, 1992). Furthermore, Sukarna et al. (1993) divided this formation into lower sequence and upper sequence. The lower sequence estimated to be formed in Eocene to Early Oligocene and has interfingering contact to Bayah Formation while the upper sequence formed in Late Oligocene to Early Miocene and has contact to Cijengkol Formation and Citarate Formation. This formation is quite thick and inserted with sedimentary rocks that are Eocene, Oligocene, to Miocene aged (Hutabarat, 2016). In some way this formation especially andesite and basalt are related to hydrothermal activity that led to the alteration and mineralization with low intensity.

Granodiorite Cihara: This group of rocks composed of granodiorite, porphyry granodiorite, granite, porphyry dacite, gabro, and apalite which have the age of the Early Oligocene to the Late Oligocene (Sujatmiko $\&$ Santosa, 1992). This group easily recognized because it has a fairly wide distribution and easily found on the Cigaber, Cisanun, Cipeusing, Cibayawak, and Cikahuruan Stream.

Based on Ahnaf et al. (2018), Granodiorite Cihara lifted due to orogenesis which then breaks through rocks that al ready exist on it. In another report, Sukarna et al. (1993) assumed that this group have a younger age i.e. Miocene which then known as Miocene plutonic and volcanic rocks (MPV). These granitic rocks have widespread and estimated to be present in the form of batholite (Hartono et al., 2008). This rock is known by van Bemmelan (1949) as the Bayah Dome due to its intrusive shape that resembles a dome. Similar to the Cikotok Formation, some of these rocks have been altered and mineralized in moderate intensity.

\section{Material and Method}

In this research, data acquisition including field observation, petrographic analysis, and geochemical analysis. The geochemical data as primary data in this research used for determining the characteristics of magma and rock tectonic environment while petrographic data used for identifying the content, texture and paragenesis of minerals. In addition, field data useful for determining the position of Granodiorite Cihara rocks among other rocks around it. Granitic rock samples were taken from two streams i.e. Cigaber and Cisanun which is represented granitic rocks in the field.
A drill and geological hammers used to obtain fresh samples during sampling. These samples then sorted according to the level of oxidation, alteration and mineralization which then fresh samples of rock brought to the laboratory for petrographic and geochemical analysis. Petrographic preparation and analysis carried out in the Lab. Petrology and Mineralogy FTG at Padjadjaran University, sample preparation including cutting to polishing the samples into thin sections which then analyzed under polarized light microscopy. The preparation and geochemical analysis carried out at Intertek Jakarta and the Bandung Geological Survey Center, this geochemical analysis used X-Ray Fluorescence (XRF) to obtain major oxide concentrations and Inductively Coupled Plasma Mass Spectrometry (ICP-MS) to obtain major and minor elements concentration including trace elements and rare earth elements (REE).

\section{Result and Discussion}

\subsection{Field Observation}

Field data was taken from the Cigaber and Cisanun Stream which represented the research area because of their complete lithology including Metamorphic Rock, Bayah Formation, Cikotok Formation, Granodiorite Cihara, and Quaternary Volcanic Rocks. As seen in Fig. 2 , rock outcrops found on the Cisanun Stream include claystone, diorite, granodiorite, amphibolite (exitu), schist, and phyllite. While from the Cigaber Stream consisted of volcanic breccia, andesite, granodiorite, and schist.

The lithostratigraphic correlation between the two stream showed that the position of M etamorphic Rock is at the bottom which is then followed by the Cihara Granodiorite, Bayah Formation, Cikotok Formation, and Quaternary Volcanic Rock same as stated by Ahnaf et al. (2018) and Patonah \& Haryadi (2018). The granodiorite position showed intrusions that break through the rock above such as the Cikotok Formation and Metamorphic Rock.

Granitic rocks (Granodiorite Cihara) that found on the Cisanun and Cigaber stream have thicknesses vary from a few meters. Besides on the river, these rocks are also found on the hill. These rocks are easily recognized because of its rough texture, quartz in these rocks have size more than $2 \mathrm{~mm}$ which is able to observed directly.

Megascopic characteristics of these granitic rocks are still the same, which have medium gray in color, coarse texture, leucocratic color index, phaneritic grains, subhedral crystalline form, panidiomorphic to hypidiomorphic mineral form, sub-equigranular crystalline relationship, and hard. Minerals those are identified megascopically i.e. quartz and feldspar. Some of these rocks are altered and mineralized with low to moderate intensity, alteration minerals appeared including clay and chlorite while mineralization in the form of pyrite and chalcopyrite. The appearance of rock outcrops and rock handspecimen samples presented in Fig. 3. 


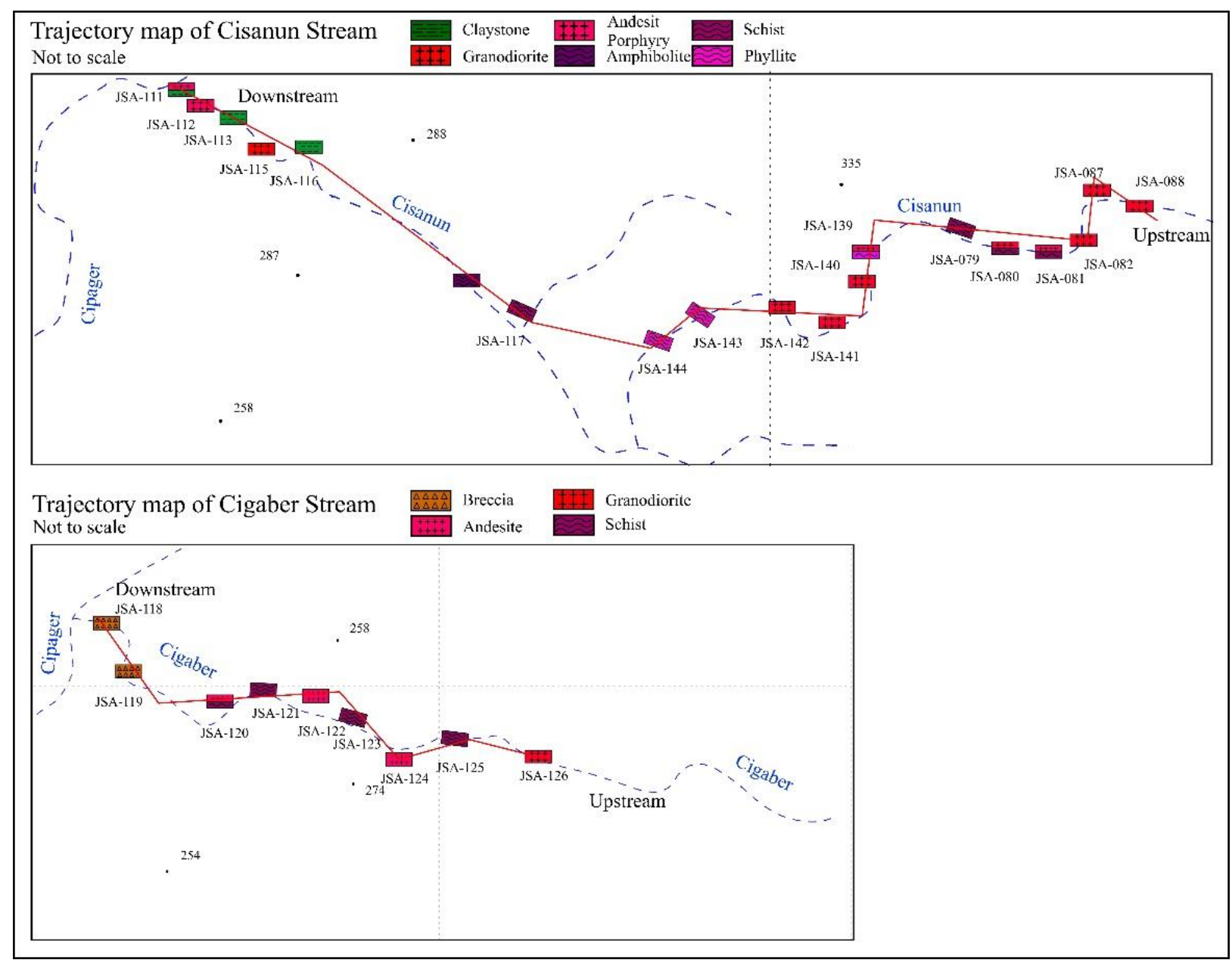

Fig. 2. Trajectoray of exposed rocks from Cisanun and Cigaber Strea.

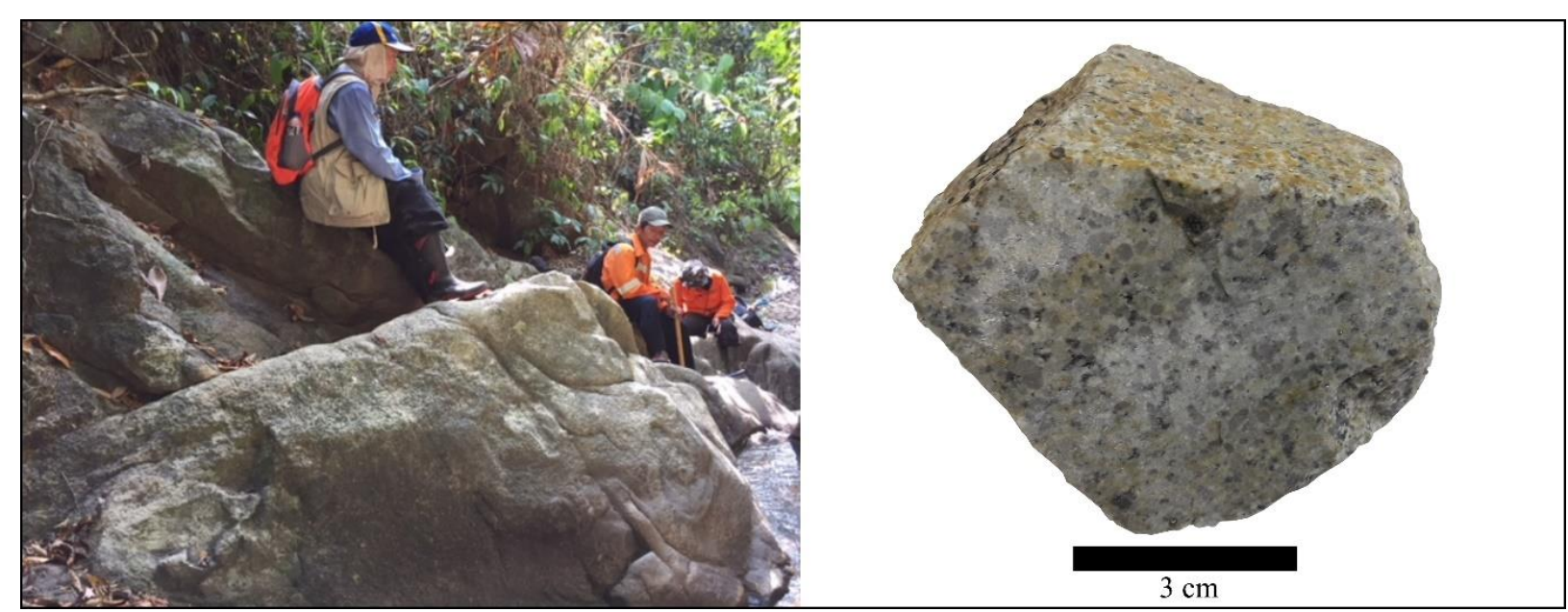

Fig. 3. Exposed granitic rock (granodiorite) and hand specimen sample. 

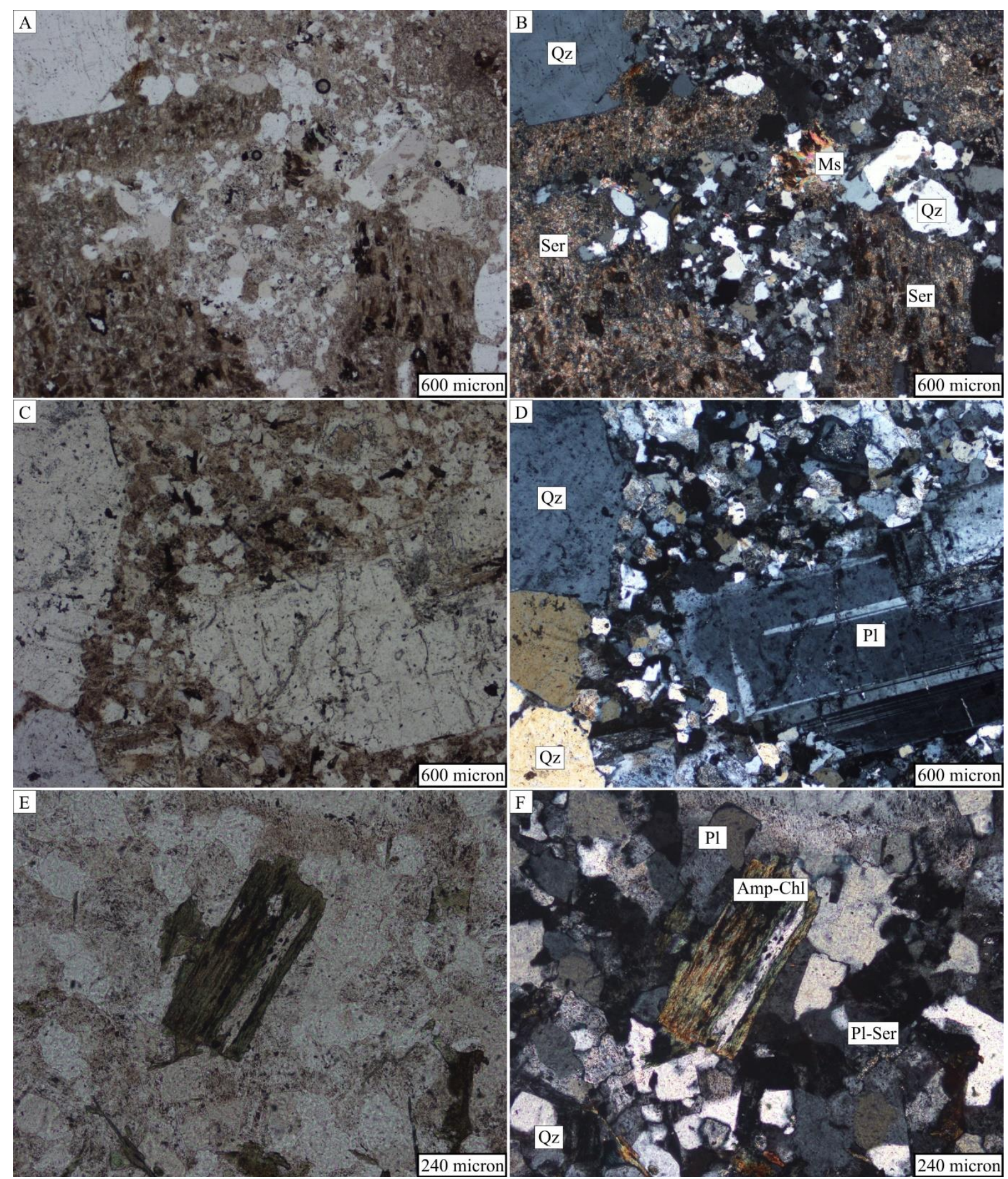

Fig. 4. Photomicrograph of granodiorite thin section. A-B showed sample JSA-142, C-D showed sample JSA-151, E-F showed chloridized-amphibole and sericited plagioclase from sample JSA-151. Identified primary minerals i.e. quartz (Qz), plagioclase (PI), muscovite (Ms), and amphibole (Amp) while secondary quartz, chlorite (Chl), and sericite (Ser) appeared as secondary minerals.

\subsection{Petrography}

Petrographic samples taken for analysis came from the Cisanun Stream (JSA-142) and Cipeusing Stream(JSA-151) where the Cipeusing Streamable to represent the Cigaber Stream because of its adjacent location. Photomicrograph of a thin section of the rocks showed in Fig. 4.

JSA-142: This thin section is colorless in color, showing porphyritic to phaneritic texture, sub-

equigranular relationship minerals, subhedral to anhedral crystals form, hypidiomorphic minerals form, primary minerals of this rock i.e. quartz, plagioclase, $\mathrm{K}$ feldspar, and muscovite, while sericite, chlorite, carbonate, and opaque minerals appeared as minerals secondary.

This thin section also refers to the poikilitic texture in which large mineral such as plagioclase surrounded by smaller minerals such as the quartz groundmass. The rock seems undergone alteration. This rock is 
composed of $60 \%$ phenocryst and $40 \%$ groundmass. Quartz, plagioclase, K-feldspar, and muscovite appeared as phenocryst while secondary/ smaller quartz and sericite as groundmass. Quartz phenocryst have size of 150 microns and more, colorless, elongated to spherical subhedral, found in almost all parts of the thin section. Plagioclase have size of 100 microns, colorless, tabular subhedral, some of these minerals altered into sericite, plagioclase type ranged from oligoclase to andesine. K-feldspar have size of 50 to 100 microns, colorless, tabular with subhedral to anhedral crystals, found in small amounts.

JSA-151: This thin section is colorless in color, showing phaneritic texture, sub-equigranular relationship minerals, euhedral to subhedral crystals form, panidiomorph to hypidiomorphs minerals form, primary minerals making up these rocks are quartz, plagioclase, K-feldspar, biotite, amphibole while secondary minerals are present in the form of chlorite, sericite, and opaque minerals. This thin section shows indistinct perthite texture.

This thin section also shows mineral alteration in weak intensity. This rock is composed of $75 \%$ phenocryst and $25 \%$ groundmass. Quartz, plagioclase, K-feldspar, biotite and amphibole appeared as phenocryst while smaller porphyritic quartz appeared as groundmass. Phenocryst quartz have size 300 microns and more, colorless, spherical subhedral, found in all parts of the thin section. Plagioclase have size of 400 microns and more, colorless, tabular euhderal, some of this mineral altered into sericite, plagioclase show extinction angle ranged from $20-25^{\circ}$ classified as andesine. K-feldpsar have size of 50 to 200 microns, colorless, tabular subhedral, these minerals are difficult to identify because their small amount and lack of twins. This thin section also shows alteration in the presence of chlorite seen to change amphibole and sericite to change plagioclase.

\subsection{Geochemistry}

There are 5 granitic rock samples to be discussed in geochemistry scope. 3 samples from this study were from the Cisanun Stream (JSA-142 and JSA 141) and Cigaber Stream (JSA-126), while 2 other samples were from Hartono et al. (2008).

Previous studies of granitic rocks in Bayah have been discussed by Hartono et al. (2008), but out of the 8 samples discussed only 2 of them were granitic rocks which in this research named $\mathrm{UH}-01$ and $\mathrm{UH}-02$ while the other 6 samples were volcanic rocks such as andesite, basalt, rhyolite, dacite and some of them are part of the Cikotok Formation.

The results of XRF and ICP-MS geochemical analysis from these samples listed in Table 1 and Table 2.

\subsubsection{Magma Series and Rock Name}

Based on the relationship between $\mathrm{N} 2 \mathrm{O}+\mathrm{K} 2 \mathrm{O}(\mathrm{A})$, FeOt $(\mathrm{F})$, and $\mathrm{MgO}(\mathrm{M})$ represented by the AFM ternary diagram after Irvine \& Baragar (1971) (Fig. 5A), rocks in the study area belong to the calc-alkali magma series. Due to high content of $\mathrm{K} 2 \mathrm{O}$, magma origin of these rocks are specified as the high- $K$ calc-alkaline series as shown in Fig. 5B. According to Yuwono (2004), calcalkali series typically found in subduction/ orogenic setting, furthermore, this calc-alkaline magma could be found in island arc or active continental margin tectonic setting.

Table 1. Major oxides in wt\%and CIPW Norm of Bayah granitic rocks.

\begin{tabular}{|c|c|c|c|c|c|}
\hline & JSA-142 & JSA-126 & JSA-141 & UH-01* & $\mathrm{UH}-02 *$ \\
\hline Oxide & \multicolumn{5}{|c|}{$\mathrm{Wt} \%$} \\
\hline$\overline{\mathrm{SiO} 2}$ & 75.55 & 74.28 & 69.68 & 67.38 & 75.68 \\
\hline $\mathrm{TiO} 2$ & 0.11 & 0.14 & 0.105 & 0.56 & 0.009 \\
\hline $\mathrm{Al} 2 \mathrm{O} 3$ & 12.52 & 13.64 & 14.64 & 15.56 & 13.39 \\
\hline $\mathrm{Fe} 2 \mathrm{O} 3$ & 2.41 & 2.75 & 2.47 & 3.93 & 1.56 \\
\hline $\mathrm{MnO}$ & 0.14 & 0.06 & 0.124 & 0.07 & 0.04 \\
\hline $\mathrm{MgO}$ & 0.45 & 0.36 & 0.91 & 1.66 & 0.49 \\
\hline $\mathrm{CaO}$ & 0.39 & 0.35 & 0.38 & 3.55 & 1.43 \\
\hline $\mathrm{Na} 2 \mathrm{O}$ & 1.97 & 2.71 & 2.20 & 3.87 & 3.76 \\
\hline $\mathrm{K} 2 \mathrm{O}$ & 4.82 & 4.31 & 5.66 & 3.1 & 3.52 \\
\hline $\mathrm{P} 2 \mathrm{O} 5$ & 0.035 & 0.049 & 0.05 & 0.21 & 0.17 \\
\hline $\mathrm{Cr} 2 \mathrm{O} 3$ & 0.02 & 0.02 & 0.01 & - & - \\
\hline LOI & 1.58 & 1.16 & 2.86 & - & - \\
\hline Total & 100.00 & 99.83 & 99.09 & 99.89 & 100.05 \\
\hline \multicolumn{6}{|c|}{ CIPW Norm } \\
\hline Mineral & \multicolumn{5}{|c|}{$\mathrm{Wt} \%$} \\
\hline Quartz & 43.31 & 39.89 & 32.25 & 22.46 & 36.41 \\
\hline Plagioclase & 18.34 & 24.34 & 20.17 & 48.68 & 37.8 \\
\hline Orthoclase & 28.48 & 25.47 & 33.45 & 18.32 & 20.8 \\
\hline Corundum & 3.45 & 4 & 4.32 & - & 1.2 \\
\hline Diopside & - & - & - & 0.25 & - \\
\hline Hypersthene & 3.19 & 3.06 & 4.34 & 6.47 & 2.56 \\
\hline Ilmenite & 0.21 & 0.27 & 0.21 & 1.06 & 0.02 \\
\hline Magnetite & 3.49 & 3.99 & 3.58 & 5.7 & 2.26 \\
\hline Apatite & 0.09 & 0.12 & 0.12 & 0.49 & 0.39 \\
\hline
\end{tabular}

Besides it also supported by typically volcanic arc with low $\mathrm{TiO} 2$ content. 4 out of 5 samples showed very low TiO2 at 0.009-0.14 wt\% and one sample (UH-01) showed slightly higher TiO2 at 0.56 wt\% In addition, granitic rocks in the study area have high $\mathrm{SiO} 2$ and $\mathrm{K} 2 \mathrm{O}$ content where $\mathrm{SiO} 2$ ranged from $67.38-75.68$ wt\%with an average of 72.51 wt\%and $\mathrm{K} 2 \mathrm{O}$ ranged from 3.10-5.66 wt\% with an average of 4.28 wt\% Thus, based on the rock classification diagram (Fig. 6), JSA-142, JSA-126, JSA-141, and UH-02 belong to granite rocks (Cox et al., 1979) or more precisely monzogranite (Streckeisen, 1976), while UH-01 is diorit-quartz (Cox et al., 1979) which is also called granodiorite (Streckeisen, 976). Classification of rocks Cox et al. (1979) is based on the content of $\mathrm{SiO} 2, \mathrm{~K} 2 \mathrm{O}$, and $\mathrm{Na} 2 \mathrm{O}$ while Streckeisen (1976) emphasized the mineral content of quartz (Q), K feldspar (A), and plagioclase (P) which in this paper determined from the CIPW Norm.

\subsubsection{Granite Type and Magma Origin}

Over the past two decades there have been two types of determinations of granitic rocks i.e. Chappell \& White (1974) and Pearce et al. (1984). Although they same determined the rocks based on geochemical data, there are advantages and disadvantages of the two types of determination. For example, determination based on Chappell \& White (1974), granitic rocks divided into I-type and S-type which are then also Mtype (White, 1979) and A-type (Collins et al., 1982), this classification able to represent its petrogenesis such as magma origin and indication for tectonic 
environments. However, the determination of the tectonic environment still less convincing because only based on major elements that are relatively less sensitive in geochemistry than trace elements.

Table 2. Minor elements concentration of Bayah granitic rocks. JSA-142 JSA-126 JSA-141 UH-01* UH-02*

\begin{tabular}{|c|c|c|c|c|c|}
\hline \multicolumn{6}{|c|}{ LFSE-LILE } \\
\hline$\overline{\mathrm{Rb}}$ & 115.00 & 108.00 & 109.90 & 42.00 & 44.00 \\
\hline $\mathrm{Sr}$ & 56.80 & 83.20 & 73.94 & 77.00 & 173.00 \\
\hline Cs & 1.70 & 2.00 & 1.52 & - & - \\
\hline $\mathrm{Ba}$ & 431.00 & 346.00 & 590.00 & 213.00 & 221.00 \\
\hline \multicolumn{6}{|c|}{ Incompatible/ Transition } \\
\hline$\overline{\mathrm{V}}$ & 5.00 & 6.00 & 5.94 & - & - \\
\hline $\mathrm{Cr}$ & 5.00 & 5.00 & 87.00 & - & 6.00 \\
\hline Co & 2.00 & 2.00 & - & - & - \\
\hline $\mathrm{Ni}$ & 5.00 & 2.00 & - & - & 146.00 \\
\hline $\mathrm{Zn}$ & 32.00 & 29.00 & 33.00 & - & - \\
\hline \multicolumn{6}{|c|}{ HFSE } \\
\hline$\overline{\mathrm{Ti}}$ & 655.00 & 791.00 & 629.00 & - & - \\
\hline $\mathrm{Y}$ & 16.30 & 15.60 & 12.55 & 11.00 & 13.00 \\
\hline $\mathrm{Zr}$ & 2.30 & 3.00 & - & 0.01 & 45.00 \\
\hline $\mathrm{Nb}$ & 5.20 & 5.20 & 4.10 & 3.00 & 5.00 \\
\hline $\mathrm{Hf}$ & $<0.1$ & 0.20 & - & - & - \\
\hline $\mathrm{Ta}$ & 0.47 & 0.45 & 1.36 & - & - \\
\hline $\mathrm{Pb}$ & 8.00 & 6.00 & 6.75 & - & - \\
\hline Th & 7.10 & 6.98 & 6.32 & 4.00 & 5.00 \\
\hline $\mathrm{U}$ & 1.25 & 1.11 & 1.15 & - & - \\
\hline \multicolumn{6}{|c|}{ REE } \\
\hline $\mathrm{La}$ & 15.00 & 17.10 & 12.23 & 10.13 & 9.33 \\
\hline $\mathrm{Ce}$ & 33.00 & 35.50 & 29.04 & 21.71 & 22.34 \\
\hline $\operatorname{Pr}$ & 4.15 & 4.38 & 2.41 & 1.98 & 2.59 \\
\hline $\mathrm{Nd}$ & 15.70 & 16.70 & 13.85 & 8.98 & 5.28 \\
\hline $\mathrm{Sm}$ & 3.50 & 3.60 & 2.76 & 2.01 & 2.18 \\
\hline $\mathrm{Eu}$ & 0.40 & 0.60 & 0.64 & 0.01 & 0.27 \\
\hline Gd & 3.20 & 3.20 & 1.85 & 1.50 & 2.24 \\
\hline $\mathrm{Tb}$ & 0.49 & 0.47 & 0.31 & - & - \\
\hline Dy & 2.90 & 2.80 & 1.71 & 1.87 & 2.22 \\
\hline Но & 0.60 & 0.60 & 0.20 & - & - \\
\hline $\mathrm{Er}$ & 1.50 & 1.70 & 0.70 & 0.61 & 1.50 \\
\hline $\mathrm{Tm}$ & 0.30 & 0.20 & 0.08 & - & - \\
\hline $\mathrm{Yb}$ & 1.60 & 1.70 & 0.97 & 0.76 & 1.69 \\
\hline $\mathrm{Lu}$ & 0.26 & 0.27 & 0.06 & - & - \\
\hline Total REE & 82.60 & 88.82 & 66.80 & 49.56 & 49.64 \\
\hline
\end{tabular}

Nevertheless the advantage of this determination is the prediction of magma origin such as I-type derived from igneous rock, S-type from sedimentary rock, Mtype from mantle, and A-type from anorogenic setting In contrast, Pearce et al. (1984) divide the type of granitic rock based on trace elements which is very useful in determining tectonic environments. In its division Pearce et al. (1984) divided the granitic rock environment into ocean ridge granites (ORG), volcanic arc granites (VAG), within plate granites (WPG), and collision granites (COLG). Thus, in this paper the two determinations of granitic rocks used where the determination based on Chappell \& White (1974) used to estimate magma origin while Pearce et al. (1984) used to determine tectonic environments.

The molar concentration of Al2O3 (A), Na2O (N), $\mathrm{K} 2 \mathrm{O}(\mathrm{K})$, and $\mathrm{CaO}(\mathrm{C})$ used to determine Shand's index (Shands, 1951) and the granite type Chappel \& White
(1974). As shown in Table 3, sample JSA-142, JSA-126, JSA-141, and UH-02 have molar A/CNK ratio $>1.0$ and classified as peraluminous index (Shands, 1951; Maniar \& Piccoli, 1989) which also classified as S-type granite. Whereas the remain sample $\mathrm{UH}-02$ has a molar $\mathrm{A} / \mathrm{CNK}$ ratio of $<1.0$ and $A / N K>1.0$ and classified as a metaluminous index of I-type granite (Shands, 1951; Maniar \& Picolli, 1989). S-type granite rocks in the study area also have low Na2O characteristics which are $<3.2$ wt\%(except UH-02), corundum $>1 \%$ and high $\mathrm{SiO} 2$ content similar to those described by Chappel \& White (2001), as well as I-type granite containing Na2O $>3.2$ wt $\%$ and corundum $<1 \%$ In addition, all rock samples analyzed were classified as Peacock's index calcic because they contained $\mathrm{SiO} 2>61$ wt\%(Peacock, 1931; Maniar \& Picolli, 1989). Thus the magma origin of granitic rocks in the research area estimated largely derived from sediment. However, Hartono et al . (2008) reported that 3 granitic rock samples in Bayah were more likely to be I-type than S-type, whereas one sample of them is peraluminous S-type granite (UH02). The results of combining data from this research and Hartono et al. (2008), granitic rocks are more likely to be S-type although there is one I-type sample. Accordingly the discussion of the original magma will be different from with Hartono et al. (2008) that stated the origin of the granitic rocks magma is the same as Cikotok Formation.

\subsubsection{Tectonic Environment}

Determination of tectonic environments based on trace elements in accordance with those recommended by Pearce et al . (1984). As shown in the Harker diagram at $\mathrm{Y}, \mathrm{Rb}, \mathrm{Nb}$ vs. SiO2 in Fig. 7, all rock samples have depleted $Y$ concentration of 11.00 ppm to 16.30 ppm with an average of 13.69 , this low $Y$ content identical to the volcanic arc granites (VAG) environment or collision granites (COLG) because high $Y$ or $Y b$ commonly found in oceanic ridge granites (ORG) and within plate granites (WPG) (Pearce et al., 1984). Similar to $\mathrm{Y}$, the $\mathrm{Rb}$ concentration of granitic rock samples also quite low at $42.00 \mathrm{ppm}$ to $105.00 \mathrm{ppm}$ with an average of 83.78 ( $<100$ ppm). Rb concentration able distinguish VAG with syn-collision granites (SynCOLG), where $\mathrm{Rb}<150 \mathrm{ppm}$ more likely to be found in the VAG than SynCOLG. The Nb concentration also shows depleted trend of $3.00 \mathrm{ppm}$ to $5.20 \mathrm{ppm}$ with an average of $4.50 \mathrm{ppm}$, this depleted $\mathrm{Nb}$ usually found in the VAG and ORG. Taking into account the concentrations of $\mathrm{Y}, \mathrm{Rb}$ and $\mathrm{Nb}$, granitic rocks in the research area are located in the volcanic arc granites (VAG) environment. Furthermore, trace elements Rb, Y, $\mathrm{Nb}, \mathrm{Ta}$, and $\mathrm{Yb}$ are plotted in the discriminant diagram after Pearce et al. (1984) in Fig. 8, where the plot results of each discriminant diagram show that the granitic rocks are located in the volcanic arc granites (VAG) correspond to the Harker diagram in Fig. 7.

In detail, VAG divided into oceanic-thoelitic, oceanic calc-alkaline, and active continental margin type. Regard to these three VAG types, VAG oceanic thoelitic likely not possible since all granitic rocks in this research are calc-alkaline to high-calc alkaline as shown in Fig. 5. 


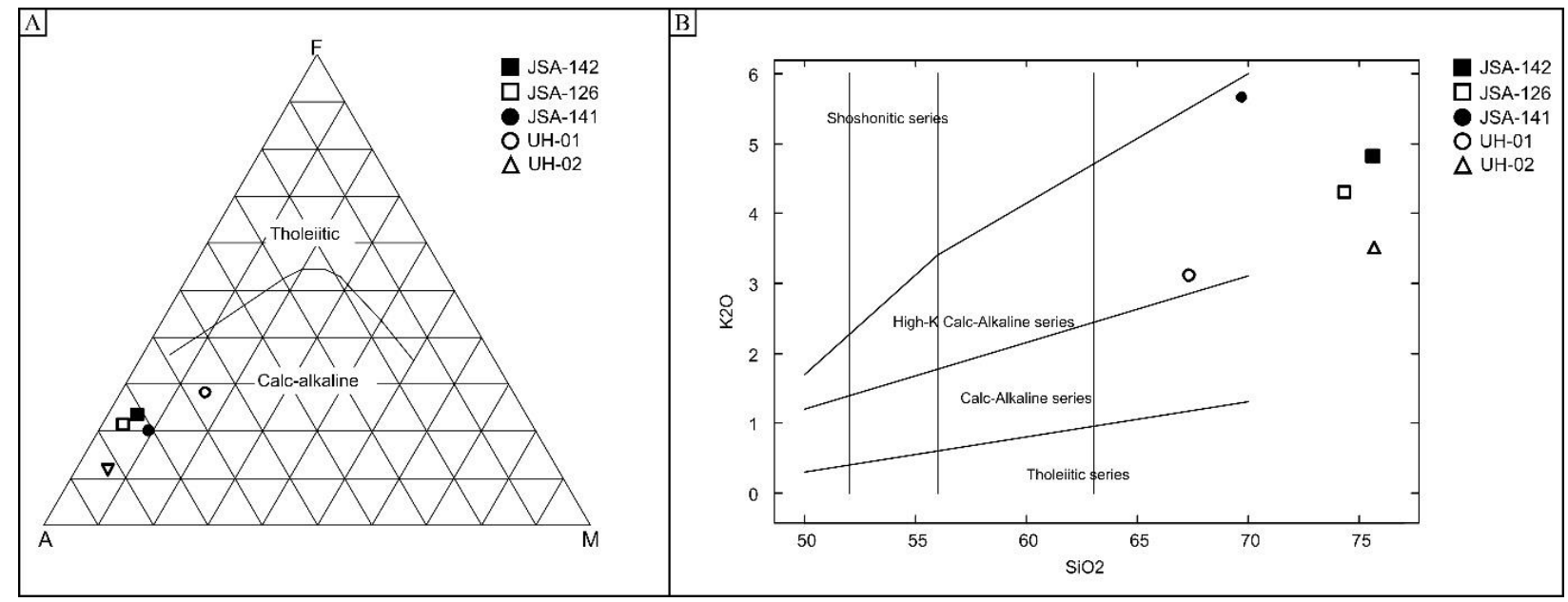

Fig. 5. (A) AFM diagram (Irvine \& Baragr, 1979) and (B) K2O vs SiO2 diagram (Peccerillo \& Taylor, 1976).

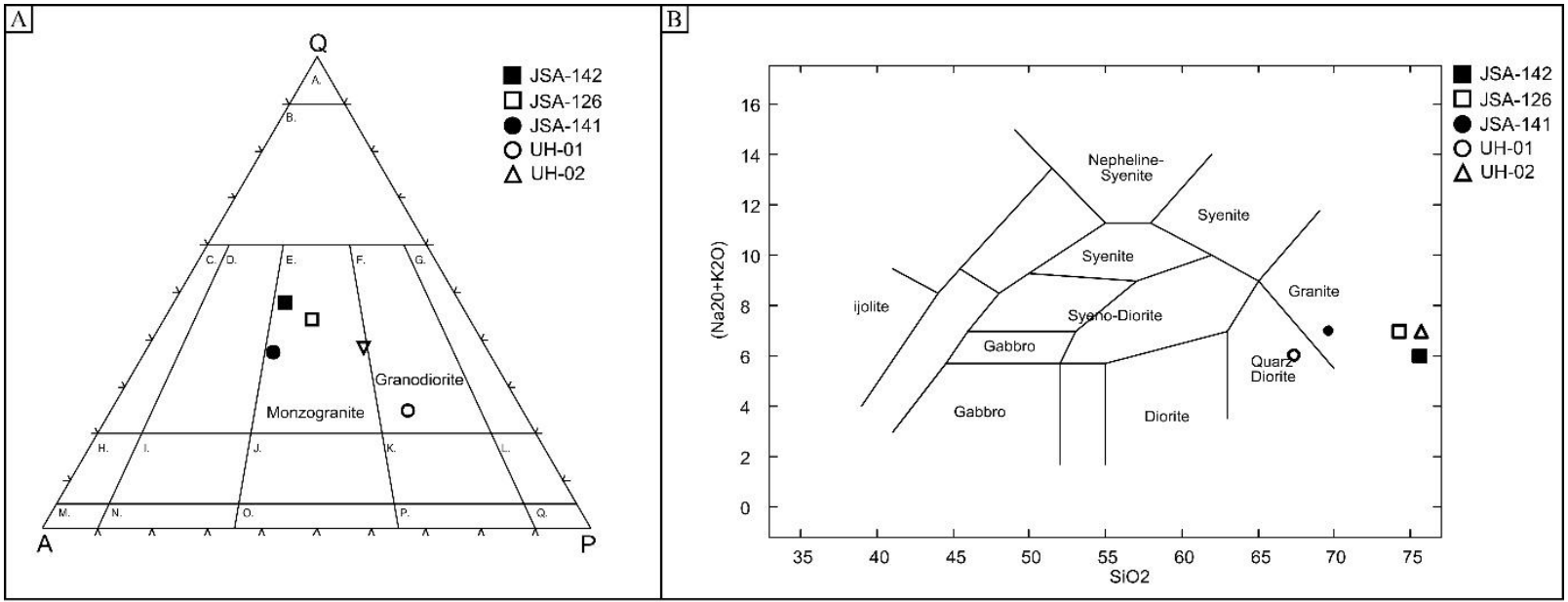

Fig. 6. Plutonic rock classification, (A) QPA diagram (Streckeisen, 1976) and (B) Na2O+k2O vs SiO2 dragram (Cox et al., 1971).

Table 3. ACNK content in molar\% Shand's index, and granite type of Bayah granitic rocks.

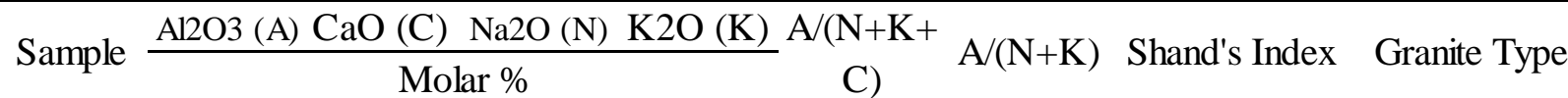

\begin{tabular}{lcccccccc}
\hline JSA-142 & 8.184 & 0.464 & 2.153 & 3.410 & 1.358 & 1.471 & Peraluminous & S type \\
JSA-126 & 8.945 & 0.417 & 2.972 & 3.059 & 1.387 & 1.483 & Peraluminous & S type \\
JSA-141 & 9.919 & 0.467 & 2.492 & 4.151 & 1.395 & 1.493 & Peraluminous & S type \\
UH-01 & 10.118 & 4.197 & 4.208 & 2.182 & 0.956 & 1.584 & Metaluminous & I Type \\
UH-02 & 8.535 & 1.657 & 4.007 & 2.428 & 1.055 & 1.326 & Peraluminous & S Type \\
\hline
\end{tabular}

VAG oceanic calc-alkaline also not likely become the environment of the rocks considering high content of Al2O3 (12.42-15.56 wt\% and low Yb (0.76-1.70 ppm) which represent continental than oceanic rocks. Thus, granitic rocks of Bayah Complex are formed in the VAG active continental margin. This tectonic environment also supported by their magma's nature of high - calc alkaline.

Referring to the regional tectonic setting, the Bayah Complex on Java Island is a part of the volcanic - island arc thta highly affected by the collision between IndoAustralian Oceanic Plate and Sunda Continental Plate (part of the Eurasian Plate) (Sukarna et al. 1993; Clements et al., 2009). The collision resulted volcanism and magmatism activities, including magmatisme in Bayah Complex. The geochemistry of granitic rocks represented by the tectonic discriminant diagrams after Pearce et al. (1984) show the suitability rock environment with the regional tectonic setting i.e. the volcanic - arc. Furthermore, the Sunda Plate is the most southeastern margin of the Eurasian Plate which moves south in contrast to the Indo-Australian Plate which moves north, both plates are at least collided in the Late Cretaceous (Sukarna et al., 1993; Ahnaf et al., 2018). 
Thus it is very fitted because geochemically the granitic rocks show volcanic - arc active continental margin. The southeast region of the Eurasian Plate known as one of the most seismically active and has a complex tectonic setting, it is not surprising that volcanism and magmatism activity have been running from Late Cretaceous untill the present time.

\subsection{Formation of Grantic Rocks}

\subsubsection{Sediment Source}

As discussed earlier, the S-type granite magma in the research area originated from sediments. By regard to regional geology, this granitic rocks known as the Granodiorite Cihara was formed in the Early Oligocene to the Late Oligocene (Sujatmiko \& Santosa, 1992). By this, it could be assumed that the sediment sources are older than the Early Oligocene. There are only sedimentary rocks from Bayah Formation and Cijengkol Formation which are older than these granitic rocks therefore one or both of these rock formations have the same source as granitic rocks.

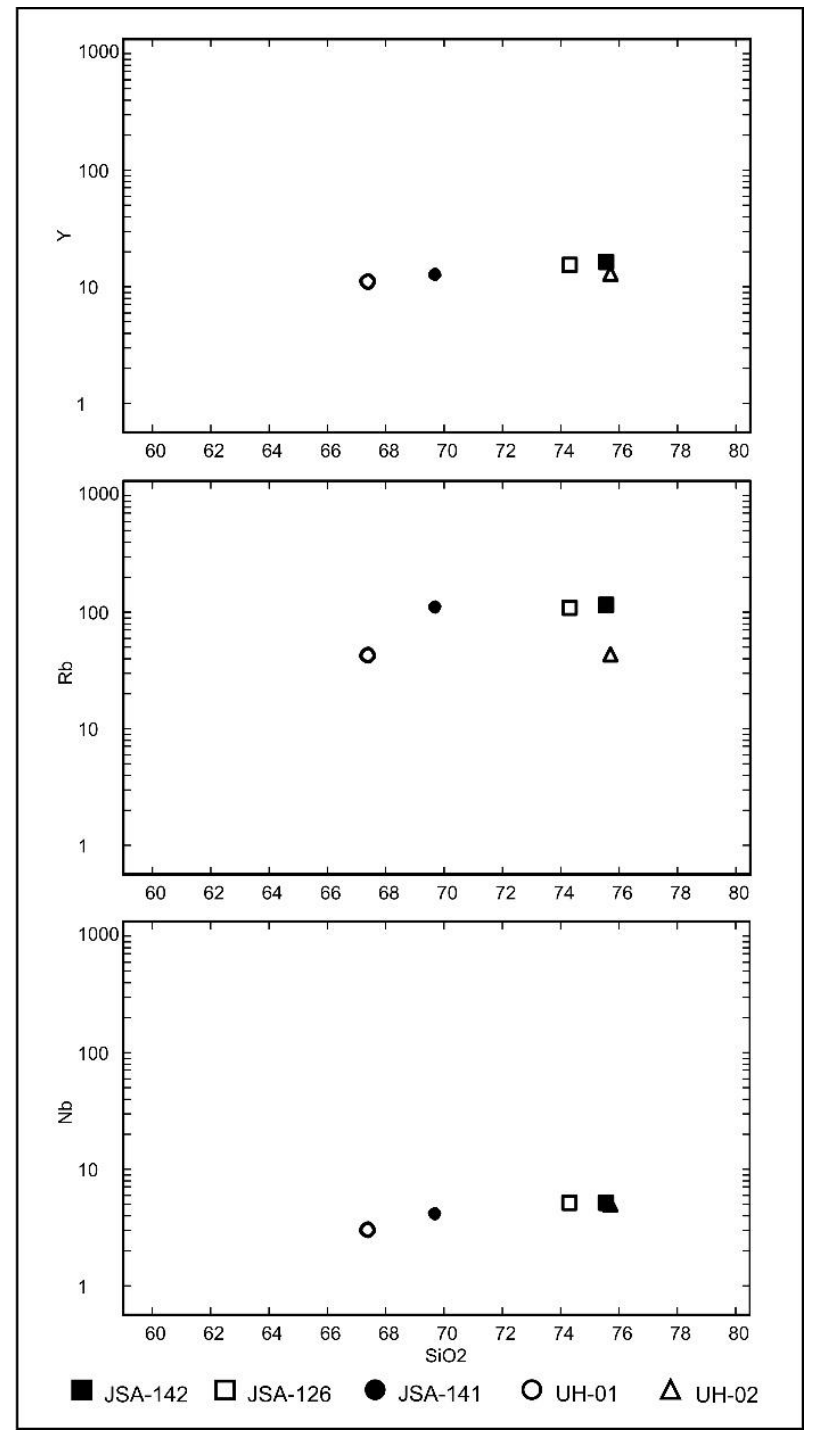

Fig. 7. Harker diagrams of $\mathrm{Y}, \mathrm{Rb}$, and $\mathrm{Nb}$ vs $\mathrm{SiO} 2$ after Pearce et al. (1984).
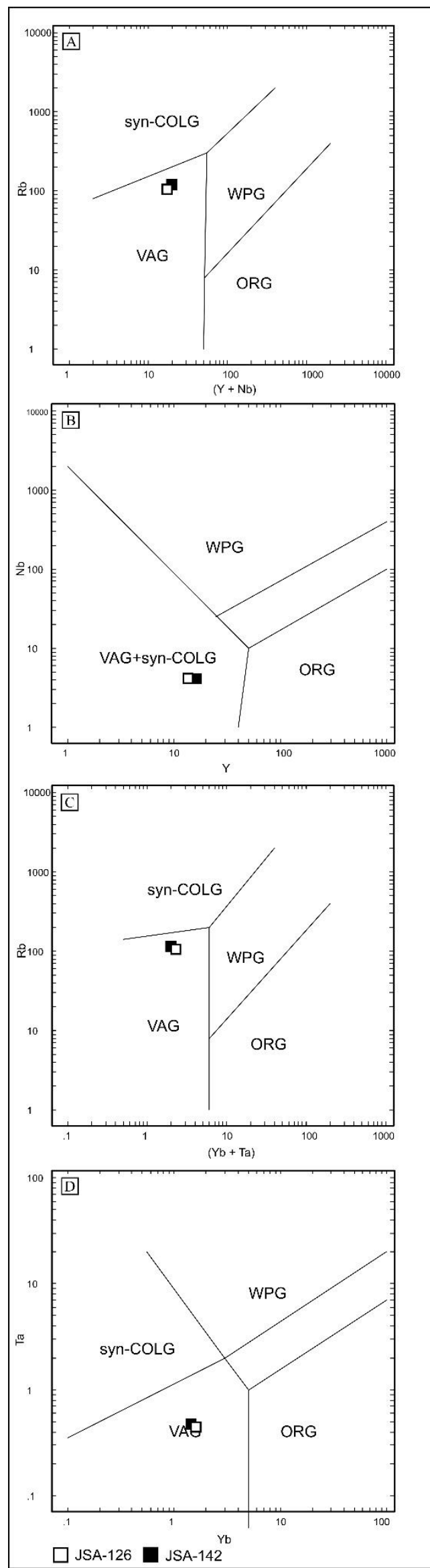

Fig. 8. Tectonic discriminant diagrams of $\mathrm{Rb}, \mathrm{Y}, \mathrm{Nb}$, and Ta after Pearce et al. (1984). 
Based on the $\mathrm{U}-\mathrm{Pb}$ dating of zircon minerals from both formations, Clements \& Hall (2008) stated that these two formations show similar zircon age signatures i.e. Early Cretaceous to Middle Cretaceous for Bayah Formation and Jurassic to Cretaceous for the Cijengkol Formation which originated from the Schwaner Mountains. Furthermore, other zircons still from the same two formations also show similar age clusters i.e. Pemian-Triassic originating from the granitic rocks of the Malay Peninsula and Indonesian Tin Island. Thus, the Bayah Formation and Cijengkol Formation sourced from several same sources, namely the Schwaner Mountains, Malay Peninsula, and Indonesian Tin Island which also as source for granitic rock magma in Bayah Complex. This statement also supported by composition of granitic rocks that geochemically originated from continental.

\subsubsection{Sediment Accumulated, Metamorphosed, Melted}

Clastic sediments from Eurasia accumulated in the marine, terrestrial, and oceanic trench at the subduction between the Indo-Australian Plate and the Sunda Plate. Sediments accumulated in the shallow marineto terrestrial formed the Bayah Formation in the Middle Eocene and the Cijengkol Formation in the Early Oligocene while the sediments in trench are metamorphosed in various depths as metasediment rocks. Metasediments those fill the shallow part then exposed in Eocene as Metamorphic Rocks whereas those fill the deep part melted as magma through partial to complete melting. Melting from metasediments according to Chappell \& White (1984); Chappell \& White (1992) occurred at $800{ }^{\circ} \mathrm{C}$ although some researchers such as Clemens \& Watkins (2001) and Johnson et al (2001) stated higher temperature at $850{ }^{\circ} \mathrm{C}$. The pure composition of this melt is unknown because direct observation is very unlikely. However, experiments have been carried out regarding the general composition of the melting of the metasediments. Montel \& Vielzeuf (1997) in Villaros (2010) stated that the nature of magma from melting is always leucocratic with $\mathrm{FeO}+\mathrm{MgO}$ below $4.00 \mathrm{wt} \%$ $\mathrm{SiO} 272.00$ wt\% and $\mathrm{Al} 2 \mathrm{O} 312$ wt\% In addition, from high field strength elements ( HFSE), light rare earth elements (LREE), and lithophile elements (LILE) in melt metasediments able to indicate the process of magma differentation.

\subsubsection{Magmatic Differentiation-Crystallization}

The average composition of granitic rocks from Bayah Complex showed $\mathrm{SiO} 272.51$ wt\% Al2O3 13.95\% and $\mathrm{Fe} 2 \mathrm{O} 3+\mathrm{MgO} 3.39$ wt \% By comparing the composition to pure sediment-derived magma from experimental after Montel \& Vielzeuf (1997), Bayah granitic rocks have increased in $\mathrm{SiO} 20.51$ wt\%and Al2O 31.95 wt\% and decreased in $\mathrm{Fe} 2 \mathrm{O} 3$ + MgO 0.61 wt\% this difference in other words stated that magma have undergone changes in composition (differentiation). Villaros (2010) explained that there are 4 types of differentiation in S-type granite magma namely magma mixing, crystal fractionation, entrainment of source material, and crustal contamination/assimilation.

By considering the composition of major and minor elements in granitic rocks it seems that magma mixing and crystallization fraction not significantly occurred. White \& Chappell (1988) stated that basalt mixing occurs when the content of $\mathrm{CaO}$ and $\mathrm{Na2O}$ are higher than the sediment-derived magma while Bayah granitic rocks only show an average value of $\mathrm{CaO} 1.22$ wt\% and Na2O 2.90 wt\% In addition Villaros (2010) stated that that magma mixing usually characterized by low LILE concentration while Bayah granitic rocks show fairly to high LILE such as Rb 42.00-115.00 ppm with an average of $83.78 \mathrm{ppm}, \mathrm{Sr} 56.80-173.00 \mathrm{ppm}$ with an average of 92.79 ppm, Ba 213.00-590.00 ppm with an average of 360.20 ppm, consequently the mixing mechanism not likely occurred. Crystal fractionation typically has more felsic and high HFSE concentration magma residues, Bayah granitic rocks are indeed more felsic than pure sediment-derived magma but have ow average HFSE concentration such as Zr 12.58 ppm, $\mathrm{Hf} 0.20$ ppm, Nb 4.50 ppm, Ta 0.76 ppm, and Th 5.88 ppm so that crystal fractionation also not significant occurred.

Remaining 2 types of differentiation, namely entrainment of source material and crustal contamination, it seems that crustal contamination more likely possible because there are increase in SiO2 0.51 wt \%and $\mathrm{Al} 2 \mathrm{O} 31.95$ wt \% and a decrease in Fe2O3 +MgO by 0.61 wt \% The continental composition which is rich in $\mathrm{SiO} 2$ and $\mathrm{Al} 2 \mathrm{O} 3$ automatically enriching magma in both $\mathrm{SiO} 2$ and $\mathrm{Al} 2 \mathrm{O} 3$ and conversely reducing $\mathrm{Fe} 2 \mathrm{O} 3+\mathrm{MgO}$, moreover this crustal contamination also implied by high $\mathrm{Rb}$ concentration (average $83.78 \mathrm{ppm}$ ) and $\mathrm{Ba}$ (average $360.20 \mathrm{ppm}$ ) which usually enriched due to interaction with crustal. After the magma differentiated, as it gets closer to the surface, the temperature will be lower and the magma slowly crystallized as plutonic rocks.

\subsubsection{Batholite Exposed}

Granitic rocks are exposed on the surface as batholite (Sujatmiko \& Santosa, 1992; Hartono et al., 2008) which became known as the Bayah Dome by van Bemmelen (1949). The batholite exposing is related to global tectonic events, Sribudiyani et al. (2003) and Ahnaf et al. (2018) stated that there were continental fragments detached from Godwana moving north near subduction zone of the Indo-Australian and Sunda Plate. As a result, orogenesa occured several times and led to the uplifting. Orogenesis in the Bayah Complex divided into 3 stages i.e. Orogenesa I in the Early Oligocene, Orogenesa II in Early to Middle Miocene, and Orogenesa III in Middle Miocene to Pliocene (van Bemmelen, 1949; Ahnaf et al. 2018). Associated with the age of granitic rocks (Granodiorite Cihara) which showed the Early - Late Oligocene, this batholite is estimated to be exposed during Orogenesa I in the Oligocene. After batholite exposed, there are also small follow-up intrusions that occurred afterwards such as dacite and quartz diorite in the Miocene. Field data showing contact between granitic rocks with Metamorphic Rock and Cikotok Formation, thus, it is interpreted that the batholite break through these two 
formations to form a dome. After that, hydrothermal process occurred and resulted in alteration and mineralization in batholite body.

\section{Conclusion}

Bayah granitic rocks are exposed on the Cisanun and Cigaber Stream along with Metamorphic Rocks, Bayah Formations, and Cikotok Formations. By petrographic analysis, these rocks composed of phenocrystalline quartz, plagioclase, $\mathrm{K}$ feldspar and other minerals such as biotite and amphibole with secondary quartz groundmass. Based on the mineral content of CIPW norm, granitic rocks classified as monzogranite and granodiorite whereas based on the content of $\mathrm{SiO} 2, \mathrm{~K} 2 \mathrm{O}$, and $\mathrm{N} 2 \mathrm{O}$ these rocks classified as granite and quartz-diorite formed from high $\mathrm{K}$ calcalkaline magma. Based on the molar ratio of Al2O3, $\mathrm{CaO}, \mathrm{Na2O}$, and $\mathrm{K} 2 \mathrm{O}$, the rocks are mostly classified as peraluminous index, furthermore, granitic rocks also classified as S-type granite. The S-type granite magma are sourced from the same clastic sediment of the Bayah Formation and the Cijengkol Formation. These sediments are thought to originate from continental especially Malay Peninsula, Indonesian Tin Island, and Schwaner Mountains. Oxide compositions of granitic rocks have increased in $\mathrm{SiO} 2$ and $\mathrm{Al} 2 \mathrm{O} 3$ and decreased in $\mathrm{Fe} 2 \mathrm{O} 3$ + $\mathrm{MgO}$ from pure composition of sedimentderived magma due to magma differentiation in the form of crustal contamination. The occurrence of crustal contamination also reflected by high concentration of $\mathrm{Rb}$ and $\mathrm{Ba}$ caused by interaction with the materials of continental crust. Bayah granitic rocks are estimated to be exposed due to regional tectonic activity that caused Orogenesa I in the Early - Late Oligocene, the rocks intruded Cikotok Formation and Metamorphic Rocks and formed the Bayah Dome. Based on the trace element concentration, especially $\mathrm{Rb}, \mathrm{Y}, \mathrm{Nb}, \mathrm{Ta}$, and $\mathrm{Yb}$, Bayah granitic rocks are formed on a volcanic-arc active continental margin in accordance with the regional tectonic setting.

\section{Acknowledgments}

The authors would like to thank colleagues in Geological Engineering Faculty, Padjadjaran University and Geotechnology Center, Indonesia Institute of Sciences for valuable discussion especially for regional geology setting and geochemistry interpretation. We also thank Mr. Sangsang and family in Lebakpeundeuy, Lebak, Banten for their help during field observation. This research is also partially funded by Padjadjaran University, we thank to everyone in charge for the fund support in this research.

\section{References}

Ahnaf, J.S., Patonah, A., Permana, H., 2018. Structure and Tectonic Reconstruction of Bayah Complex Area, Banten. Journal of Geoscience, Engineering, Environment, and Technology 03 (02), 77-85.

Chappell, B.W., White, A.J.R., 1974. Two Contrasting Granite Types. Pacific Geology 8, 173-174.

Chappell, B.W., White, A.J.R., 1992. I-and S-type ranites in the Lachlan Fold Belt. Earth and Environmental Science Transactions of the Royal Society of Edinburgh 83(1-2), 126.
Clemens, J., Watkins, J.M., 2001. The fluid regime of hightemperature metamorphism during granitoid magma genesis. Contributions to Mineralogy and Petrology, 140(5), 600-606.

Clements, B., Hall, R., 2008. U-Pb Dating of Detrital Zircons from West Java Show Complex Sundaland Provenance. Proceeding of 32nd Indonesia Petroleum Association Annual Convention.

Clements, B., Hall, R., Smyth, H.R., and Cottam, M.A. 2009. Thrusting of a Volcanic Arc: a New Structural Model for Java. Petroleum Geoscience 15, 159-174.

Collins, W.J., Beams, S.D., White, A.J.R., Chappell, B.W., 1982. Nature and Origin of A-type Aranites with Particular Reference to Southeastern Australia. Contributions to mineralogy and petrology 80(2), 189-200.

Cox, K.G., Bell, J.D., Pankhurst, R.J., 1979. The interpretation of igneous rocks, George Allen and Unwin.

Hartono, U., Syafri, I., Ardiansyah, R., 2008. The Origin of Cihara Granodiorite from South Banten. Jurnal Geologi Indonesia 03 (02), 107-116.

Hutabarat, J., 2016. Geokimia Batuan Vulkanik Formasi Cikotok di Segmen Utara Kubah Bayah, Banten. Bulletin of Scientific Contribution 14 (02), 195-204.

Irvine, T.N., Baragar, W.R.A. 1971. A Guide to the Chemical Classification of the Common Volcanic Rocks. Canadian Journal of Earth Science 8, 523-548.

Johnson T. E., Hudson N. F. C., Droop G., 2001. Partial melting of the Inzie Head gneisses: The role of water and a petrogenetic grid in KFMASH applicable to anatectic pelitic migmatites. J. Metam. Geol. 19, 99-118.

Koolhoven, W.C.B., 1993. Geological map of Java, scale 1:100.000. Explanatory notes to sheet 14 (Bajah), 42p. Bandung: Geological Research and Development Centre (unpubl).

Maniar, P.D., Piccoli, P.M., 1989. Tectonic Discrimination of Granitoids. Geological Society of America, Bulletin 6, 129198.

Montel, J.M. , Vielzeuf, D., 1997. Partial melting of metagreywackes, Part II. Compositions of minerals and melts. Contributions to Mineralogy and Petrology 128(23), 176-196

Patonah, A., Permana, H., 2018. Basement Characteristic Western Part of Java, Indonesia: Case Study in Bayah Area, Banten Province. International Journal on Advanced Science Engineering Information Technology 08 (05), 2135-2141.

Patonah, A., Syafrie, I., Ayasa, H., 2014. New Perspective on High-Grade Metamorphic Regional in Bayah Complex, Banten Province, Indonesia. Proceeding 1st International Conference Geoscience for Energy, Mineral Resources and Environment.

Peacock, M.A., 1931. Classification of igneous rock series. The Journal of Geology 39(1), 54-67.

Pearce, J.A., Harris, N.B.W., Tindle, A.G.W., 1984. Trace Element Discrimination Diagrams for the Tectonic Interpretation of Granitic Rocks. Journal Petrology 25, 956-983.

Peccerillo, A. and Taylor, S.R., 1976. Geochemistry of Eocene Calc-alkaline Volcanic Rocks from the Kastamonu Area, Northern Turkey. Contribution to Mineralogy and Petrology 58, 63-81.

Shand, S.J., 1951. Eruptive Rocks. J. J. Wiley, New York.

Sribudiyani, Muchsin, N., Ryacudu, R., Kunto, T., Astono, P., Prasetya, I., Sapiie, B., Asikin, S., Harsolumakso, A.H., Yulianto, I., 2003. The Collision of the East Java Microplate and Its Implication for Hydrocarbon Occurrences in the East Java Basin. Proceeding of 29th Indonesian Petroleum Association Annual Convention.

Streckeisen, A., 1976. To each plutonic rock its proper name. Earth-science reviews 12(1), 1-33.

Sujatmiko, Santoso, S., 1992. Regional Geology Map Quadrangle Leuwidamar. Geological Development and Research Center, Bandung. 
Sukarna, D., Mangga, S.A., Brata, K., 1993. Geology of the Bayah Area: Implication for the Cenozoic Evolution of West Java, Indonesa. Geology Society of Malaysia 33, 163-180.

Van Bemmelen, R.W., 1949. The Geology of Indonesia. Martinus Nijhoff, Den Haag. Villaros, A., 2010. Petrogenesis of S-type granite with particular emphasis on source processes: The example of the S-type granite of the Cape Granite Suite (Doctoral dissertation, Dissertation. Stellenbosch University).

White, A.J.R., 1979. Sources of Granite Magma. Geological Society of America Program with Abstracts 11, 539.

Widiaputra, T., Patonah, A., 2016. Metamorphic Rocks in Bayah Complex, Banten Province: A Study in Tectonic Environment. Proceeding Of Geosea XIV and 45th IAGI Annual Convention 2016 Ikatan Ahli Geologi Indonesia ( IAGI ), 885-939.

Yuwono, Y.S., 2004. Diktat Pengantar Petrogenesis. Geological Engineering Department. FITB, Bandung Institute of Technology, Bandung.

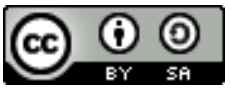

(c) 2019 Journal of Geoscience, Engineering, Environment and Technology. All rights reserved. This is an open access article distributed under the terms of the CC BY-SA License (http://creativecommons.org/licenses/by-sa/4.0/). 